\title{
«Monarquías y tiranías»: la estatua de Nabuco en Quevedo*
}

\author{
Adrián J. Sáez \\ Università Ca' Foscari Venezia \\ adrianj.saez@unive.it
}

Recepción: 24/10/2017, Aceptación: 14/04/2018, Publicación: 11/12/2018

\begin{abstract}
Resumen
Dentro de los diversos ejercicios de poesía escultórica de Quevedo examinados en otras ocasiones (los poemas a las esculturas de reyes, un madrigal amoroso, etc.), en este trabajo se pretende examinar una variante moral mediante el ejemplo de los sonetos «A la Soberbia» (con dos versiones) y "Amenaza a los tiranos», en diálogo con toda una serie de comentarios especialmente desarrollados en los tratados Providencia de Dios y Virtud militante (1651), que permiten acercarse tanto a ciertas posibilidades de la evidentia como a un nuevo caso de reescritura.
\end{abstract}

\section{Palabras clave}

Quevedo; arte; escultura; estatua; Nabuco; poesía moral; poesía religiosa; reescritura

\begin{abstract}
"Monarchies and Tyrannies": Nabucco's Statue in Quevedo

Within the distinct modalities of Quevedo's sculptural poetry examined on other occasions (poems to the statues of monarchs; the madrigal "Retrato de Lisi en mármol", etc.), this work aims to study a moral variation through the case of the sonnet "To Pride, with the Example of Nabucco's Statue" (with two versions), in dialogue with other prose commentaries, which allows certain possibilities of the evidentia to be explored, along with a new exercise in rewriting.
\end{abstract}

\section{Keywords}

Quevedo; art; sculpture; statue; Nabucco; moral poetry, religious poetry; rewriting

\footnotetext{
* Este trabajo se enmarca en el proyecto SILEM: Sujeto e institución literaria en la Edad Moderna (referencia FFI2014-54367-C2-1-R del Ministerio de Economía y Competitividad, Gobierno de España) coordinado por Pedro Ruiz Pérez (Universidad de Córdoba). Una primera versión fue presentada en el XIII Congreso Internacional de la Society for Renaissance and Baroque Hispanic Poetry (Sevilla, Universidad de Sevilla, 18-20 de octubre de 2017). Para mi fortuna, he contado con los generosos y valiosos consejos de Antonio Azaustre Galiana (Universidade de Santiago de Compostela) y Fernando Plata (Colgate University), maestros y amigos quevedianos, al tiempo que María José Alonso Veloso (Universidade de Santiago de Compostela) me ha permitido manejar material del mayor interés.
} 
Como buen humanista todoterreno, Quevedo conocía bien el paño del arte del Siglo de Oro y en su poesía se pueden hallar rastros muy variopintos de escultura, pintura y tapicería según diferentes alcances, funciones y sentidos. ${ }^{1}$ Dentro de los poemas estatuarios quevedianos (Sáez 2017a, 2017 c y 2018), la estatua de Nabuco posee una dimensión menos artística y más ejemplar (moral o religiosa) que, sin embargo, permite explorar la vertiente de la evidentia como gráfica plasmación del pecado. ${ }^{2}$

Así, en este trabajo se pretende examinar el ejemplo de la estatua de $\mathrm{Na}$ buco, tan querido por Quevedo, tanto en poesía (sonetos «A la Soberbia» y "Amenaza a los tiranos») como en prosa (tratados de todo pelo) para abordar la función del mecanismo de la evidentia, que de paso permite demostrar una vez más el gusto por la reescritura del poeta (la intertextualidad genérica que dice Ettinghausen 1995) y se relaciona igualmente con su "casi obsesión por las piedras» (Fernández Mosquera 2004: 11, y 2005). ${ }^{3}$

\section{Nabuco en el soneto}

Además de un par de poemitas sobre la cena del rey Baltasar («Espántase de la advertencia quien tiene olvidada la culpa» $\mathrm{y}$ «Modo y estilo con que la justicia de Dios procede contra los reyes», núms. 128 y 170) que toca de refilón la materia, el exemplum de Nabuco se presenta en los sonetos "A la Soberbia" (h. 1640-1645, núm. 127, con dos versiones) y «Amenaza a los tiranos» (h. 1614, núm. 181):4

1. Ver en general Sáez (2015a, 2015b, 2015c, 2015d, 2015f, 2017a y 2017b, 2018 y en prensa) y el repaso de Rubio Árquez y Sáez (2017).

2. Así, «estatua» se entiende más bien cual «representación de los falsos dioses», en palabras de Covarrubias. Davenport (2016) señala otros ejemplos de esculturas idólatras en Quevedo en $E l$ mundo por de dentro y algunos poemas y Nider (2017) atiende a las estatuas de la cortesana Friné en dos sonetos (núms. 102-103).

3. Fernández Mosquera (2005: 110, n. 65) solo apunta algunos de los casos comentados infra, que considera fuera de un uso sistemático del léxico. Para los exempla morales (históricos, literarios y contemporáneos), ver Rey (1995: 122-125).

4. Con ocasionales retoques de puntuación, cito por las ediciones consignadas en la bibliografía, de donde tomo igualmente las fechas. La datación, que tiene que considerarse solamente indicativa, procede de Roig Miranda (1989: 484-494). Sobre los epígrafes quevedianos, que muchas veces proceden de González de Salas, ver Alonso Veloso (2012). No voy a entrar en las variaciones reescriturales entre las dos versiones del primer poema: baste decir que la redacción seleccionada parece la segunda y final, mientras que el texto de Las tres musas últimas corresponde con la propuesta inicial (en copia de un autógrafo, según Blecua 1969-1981: I, 250), y parece que el poeta contemplaba la publicación de ambos textos, cada uno con su propio emplazamiento, epígrafe y sentido (Rey 1999: 31 y 107; Vallejo González 2017: 116-118). Ver, además, Tobar Quintanar (2013: 348-349). 


\begin{tabular}{|c|c|}
\hline $\begin{array}{l}\text { «Comparación de las fábricas de la Soberbia } \\
\text { con las de la humildad» } \\
\text { (El Parnaso español, } \\
\text { Madrid, Diego Díaz de la Carrera, 1648) }\end{array}$ & $\begin{array}{l}\text { "Amenaza a los tiranos, que, fiados } \\
\text { en los metales preciosos en que crecen, } \\
\text { pretenden prevalecer contra la piedra sobre } \\
\text { la que fundó Cristo su Iglesia, con la similitud } \\
\text { de la estatua de Nabuco» } \\
\text { (Las tres musas últimas castellanas, } \\
\text { Madrid, Imprenta Real, 1670) }\end{array}$ \\
\hline $\begin{array}{l}\text { Es la soberbia artífice engańoso, } \\
\text { de su fábrica pompa y no provecho: } \\
\text { ve, Nabuco, la estatua que te ha hecho, } \\
\text { advierte el edificio cauteloso. } \\
\text { Hizo la frente del metal precioso, } \\
\text { armó de plata y bronce cuello y pecho; } \\
\text { y, por trocar con el cimiento el techo, } \\
\text { los pies labró de barro temeroso. } \\
\text { No alcanzó el oro a ver desde la altura } \\
\text { la guija, que rompió con ligereza } \\
\text { el polvo en quien fundó rica locura. } \\
\text { El que pusiese el barro en la cabeza } \\
\text { y a los pies del metal la lumbre pura, } \\
\text { tendrá, si no hermosura, fortaleza. }\end{array}$ & $\begin{array}{l}\text { Las puertas del infierno siempre abiertas } \\
\text { no prevalecerán contra la nave } \\
\text { y la piedra, ¡y quieres tú, contra su llave, } \\
\text { que prevalezcan tus nefandas puertas! } \\
\text { Tan condenadas, aunque no tan muertas } \\
\text { almas, tu seno como el suyo cabe, } \\
\text { y como en él no hay voz que a Dios alabe, } \\
\text { la tuya blasfemar a Dios despiertas. } \\
\text { Estatua de Nabuco, que, tirana, } \\
\text { tan diversos metales atesora, } \\
\text { en que estás menos rica que galana, } \\
\text { advierte que en sus máquinas, traidora, } \\
\text { la piedra derribó la estatua vana, } \\
\text { no la estatua a la piedra vencedora. }\end{array}$ \\
\hline
\end{tabular}

Uno desde el ámbito moral (de Polimnia) y otro más religioso (Urania), ambos poemas se basan en el sueño del emperador Nabucodonosor (Daniel, 2, 31-45), que hace juego con la efigie dorada construida poco después en la fábula bíblica $(3,1-23)$ y poseía un potencial simbólico y didáctico que se podía aprovechar en la época como emblema de la idolatría, la soberbia y la tiranía, con sus peligros aparejados (la destrucción de los imperios). ${ }^{5}$

Por de pronto, el manejo del hipotexto bíblico es parejo en los dos sonetos, ya que seleccionan únicamente la presentación y la interpretación del sueño (Daniel, 2, 31-45), y lo reelaboran a su antojo con modificaciones tanto de disposición como de sentido: de hecho, para empezar se puede decir que el primer poema se dedica por completo al lance, mientras el segundo soneto solo es estatuario a medias (en los tercetos), por lo que se puede tener por una versión en miniatura (un boceto) del anterior, con cambio de destinatario incluido (de Nabuco a la estatua).

Esta pareja de poemas es un buen botón de muestra de la reescritura de Quevedo, pues de un tema saca dos poemas de factura y valor distintos: un aviso moral contra la soberbia y una advertencia político-religiosa contra la tiranía. ${ }^{6}$ Así, en el

5. Ver Blanco (2004) acerca de un tríptico de autos sacramentales de Calderón, que conecta con la idea de monarquía absoluta. Para la Biblia en Quevedo, ver Arellano (2004) y Nider (2008). Moreno Castillo (2014: 301) señala algunos posibles recuerdos italianos de Marino.

6. La presencia de redacciones del poema en las musas morales y religiosas hace posible ver una doble exégesis: sobre las relaciones entre ambas modalidades, ver Rey (1995: 19-20). De la estrategia reescritural quevediana, caracterizada por una profunda intertextualidad de conceptos, temas y palabras, ver Fernández Mosquera (2010: 24-26). 
primer soneto se aconseja huir de los engaños («fábrica pompa», «rica locura», vv. 2 y 11) para adoptar la humildad (representada por el barro y el polvo, 'la ceniza') como regla de conducta y lograr fortaleza de ánimo y hermosura espiritual, al tiempo que el segundo se estructura como una crítica de una mala praxis política (la simonía) y de la vana acumulación de riquezas aparentes («menos rica que galana», v. 11), que son realmente frágiles frente a la fuerza de la Iglesia. ${ }^{7}$

En ambos casos la estatua de Nabuco es la «similitud» — según uno de los epígrafes- escogida para marcar el contraste y potenciar la lección, que adquiere un matiz propio en cada poema: en uno parece acentuarse la mala distribución estructural de los elementos en una suerte de clave arquitectónica con mucho de sentido común, y en el otro se marca la vanidad — y debilidad- de la avaricia, que remite al tópico desprecio de las apariencias.

La apuesta ideológica configura la articulación de cada soneto: en «A la Soberbia» se establece de inicio una metáfora artística —entre arquitectónica y escultórica- a partir del concepto de la soberbia como "artífice engañoso» en la presentación (vv. 1-4), que da pie a la descriptio de la estatua de Nabuco con los materiales invertidos (vv. 5-8) y su simbólica destrucción por una simple "guija» ('piedra', vv. 9-11), para rematar con la exégesis de la lección ex contrario (vv. 12-14); a su vez, el otro principia con la definición del mal mediante una contraposición entre la Iglesia («nave», "piedra», «llave») y el infierno que reescribe palabras bíblicas (Mateo, 16, 18) (vv. 1-4), y la crítica al pecado de los tiranos (vv. 5-8), que se ilustra con el ejemplo de la falsamente rica estatua de Nabuco (vv. 9-11) y la advertencia final sobre la victoria de la piedra eclesiástica (fe, religión) sobre la estatua (riqueza, vv. 12-14). ${ }^{8}$

En este orden de cosas, se pueden señalar otro par de detalles: la pequeña licencia del poema soberbio de simplificar la distribución gradual de los materiales de la estatua (el cuello plateado frente al pecho y los pies solo de barro, que no "mitad de hierro y mitad de barro», Daniel, 2, 32-33) para perfeccionar la coherencia y la fuerza simbólica, así como el reajuste del sentido figurado del conjunto, que deja de ser alegoría política de la sucesión y caída de los grandes imperios hasta la venida del reino de los cielos para adoptar un valor moral relacionado con la locura, la riqueza, la soberbia y sus opuestos. ${ }^{9}$

7. Candelas Colodrón (2006: 644) emparenta el primer poema soberbio con otros dos sonetos («Reprehende la insolencia de los que se atreven a preguntar a Dios las causas por qué obra y deja de obrar» y «A la soberbia y la humildad», núms. 133 y 157) por la metáfora del barro o polvo como signo de la fragilidad humana y la gravedad del pecado de soberbia, que permite enlazar naturalmente con el tema de la ceniza.

8. Candelas Colodrón (2006: 662) añade ecos de Job $(38,17)$ e Isaías $(60,18)$, Moreno Castillo (2017: 357) suma otro de Mateo (16, 19). Ver otros intertextos (1 Timoteo, 2, 4 y muchos más) en Vallejo González (2017: 346-349), que explica la combinación de pasajes vetero- y neotestamentarios con un trasfondo común como un rasgo propio de Quevedo relacionado con el saber patrístico (2017: 49, n. 196).

9. Con algo de exceso, Vallejo González (2015: 132-133) entiende que se marca la relación del 


\section{Nabuco en los tratados}

En el universo de la prosa quevediana, la estatua de Nabuco aparece aquí y allá, por lo que de entrada se puede deslindar entre los comentarios fugaces en algunos tratadillos de diverso signo (Premáticas del Desengaño contra los poetas güeros, Discurso de las privanzas, Homilia a la Sanctísima Trinidad, y Consideraciones sobre el Testamento Nuevo y la vida de Cristo, Papel de las cosas corrientes en la corte, por abecedario, Marco Bruto y La caída para levantarse) y el comentario más detallado y extenso en Providencia de Dios y Virtud militante, que emparenta más directamente con las versiones poéticas. ${ }^{10}$

Todo parece arrancar en un discurso chistoso, para desarrollarse seguidamente a medio camino entre las reflexiones morales, políticas y religiosas:

1. Primero vale como refuerzo final de la burla de las tópicas metáforas preciosistas en las Premáticas del Desengaño contra los poetas güeros (h. 1605): "Y por cuanto el siglo está pobre y necesitado de oro y plata, mandamos que se quemen las coplas de los poetas, como franjas viejas, para sacar el oro y la plata que tienen, pues en sus versos hacen sus ninfas de todos metales, como estatua de Nabuco» (núm. 4, 13).

2. En el Discurso de las privanzas (h. 1609) se maneja como ejemplo negativo para remachar la conveniencia de un buen privado («sabio, virtuoso y prudente», II, 111) para el rey: «No permetía la estatua de Nabuco tampoco, tras tantos metales preciosos y fuertes, los pies de barro» (II, 112).

3. El valor habitual se mantiene en las atribuidas Consideraciones sobre el Testamento Nuevo y la vida de Cristo (h. 1623) como ejemplo de la ambición y necedad de los pequeños «en las cualidades de nobleza, juicio, letras, espíritu, etc.» (815): «La estatua que vio Nabuco y en que este se retrataba, tenía los pies de barro y lo demás era lo rígido, inflexible y impenetrable de los metales. Claro está que, a fundamentos de barro, ¿qué había de seguirse, sino durezas de bronce y asperezas de hierro? Así lo muestra la experiencia» (818).

4. A su vez, en medio de un comentario sobre la soberbia pintado con la torre de Babel, se hace uso del caso bíblico en la Homilía a la Sanctísima Trinidad (década de 1630): «Levantóse la soberbia estatua que vio Nabuco, desde el

oro de la cabeza «con la obstinación de aquellos que cifran su existencia en la vana acumulación de riquezas» en conexión con un pasaje del Eclesiastés $(31,7)$, junto con un «olvido del poder que Dios ejerce sobre sus vidas».

10. Con buen criterio, Alonso Veloso (2018) se limita a consignar el último título (salido de la tradición crítica) como "textos atribuidos». Un catálogo parcial ya se encuentra en Moreno Castillo (2014: 300) y Vallejo González (2017: 50), que amplío y completo. La relación del primer poema - que no el segundo - con los pasajes de Virtud militante y Providencia de Dios se señalan habitualmente de pasada, si bien Candelas Colodrón (2006: 644; y 2007: 43-44) ya le dedica algunos breves comentarios. Vallejo González (2017: 80) juzga que la concordancia con los pasajes de las prosas en cuestión refuerza la hipótesis de que los epígrafes fueran obra de Quevedo. Otro ejemplo parejo en Varela Gestoso (1998). 
lodo de sus pies, por todos los metales, hasta el oro; y una guija que cayó de un monte sin manos la derriba, que para derribar al soberbio que se levanta no es menester tener manos sino caer» (213).

5. Se le da un pequeño giro satírico en el Papel de las cosas corrientes en la corte, por abecedario (1632): y es que los "[f]avores con los extremos de la estatua de Nabuco» (374) conforman un lanzazo contra la flojedad y la inconstancia de los cortesanos.

6. En el Marco Bruto (Madrid, Diego Díaz de la Carrera, 1644, pero escrito en 1631) es emblema de la fragilidad de los reinos, lo que casa perfectamente con un pasaje en el que se critica la estrategia de acoso y derribo contra César realizada mediante diademas y pasquines en su efigie para que el pueblo «le publicase tirano y no dictador» (794), de modo que añade una nueva «dimensión a la ejemplaridad» (Krabenhoft 1994: 102): ${ }^{11}$

Y advertid que hay quien pone la corona en la cabeza para quitar la cabeza con la corona. En la cabeza la estatua de César fue su ruina una diadema; en los pies de la estatua de Nabuco, una guija: de pies a cabeza sois peligrosos. Dotrina son estas dos estatuas: honra añadida os enferma la cabeza, que sois vosotros; pequeño golpe de cosa pequeña os deshace los pies, que son vuestros vasallos. Según esto, vuestro cuidado ha de ser no consentir para vosotros demasiada grandeza, ni para ellos aun pequeño golpe (795-796).

7. Dentro del elogio de las virtudes de san Pablo y en combinación con la historia de David y Goliat (I Samuel, 17, 1-7) se presenta en La caida para levantarse (Madrid, Diego Díaz de la Carrera, 1644):

No son aparato de Dios gentileza y fuerzas corporales, ni las bravatas del aspecto, sino lo hazañoso del espíritu y lo recto de la intención: alistó una guija contra una estatua, que desde el oro al hierro fortalecían todos los metales; otra contra el filisteo, que se ostentó promontorio humano: la una tuvo vitoria por los pies, la otra por la cabeza, para advertir que de pies a cabeza acaba con las amenazas de la soberbia una china (164).

Con más detalle y una cercanía notable a los poemas anteriores se presenta en otros dos tratados morales, según ya veía Candelas Colodrón (2006: 644-645 y 2007: 43-44). Para comenzar, en Providencia de Dios (1641-1642) es ilustración de la soberbia:

Mal arquitecto es la soberbia: fabrica contra el arte. Miremos la estatua de Nabuco: lo fuerte y sólido puso en el tejado, haciendo de oro la cabeza y el barro en los ci-

11. En este hiato entre la redacción y la publicación se encuentra el paso de Quevedo por la prisión de San Marcos de León (1639-1643), con posibles idas y venidas sobre el texto en forma de reescritura, pero que acaso apunten a la preparación de una segunda parte más que a otra cosa. Ver los comentarios de Alonso Veloso (2012: 643-648). 
mientos haciendo dél los pies. La Iglesia a los pies pone el oro y el polvo en la frente y sobre la cabeza; y esto lo hace ne offendas ad lapidem pedem tuum, cuando una guija es sobrada munición contra los pies de aquel coloso, que gastó el metal, el bronce y el hierro en lo que no había de ser combatido, y dejó sin armas la flaqueza de toda su fortificación. Todos nuestros desvelos son este sueño de Nabucodonosor, pues ni ponemos cosa alguna en su lugar y lo erramos todo de pies a cabeza (261-262). ${ }^{12}$

La apertura del pasaje remite a las claras al incipit del primer soneto a Nabuco con la equiparación de la soberbia con un "mal arquitecto» ("artífice engañoso» en el poema, v. 1) y la desviación de toda lógica de la estatua, que en este tratado se completa con un significativo contraste con la Iglesia: un careo que se traduce en la dialéctica de soberbia-humildad e idolatría-religión verdadera, que en la glosa acarrea el desengaño de las riquezas y se refuerza con una conexión con el ritual del Miércoles de Ceniza («pone [...] el polvo en la frente») y una sentencia bíblica (Salmos, 90, 12; Lucas, 4, 11; y Mateo, 4, 6) (López Poza 2015: 262).

Por fin, en Virtud militante (Zaragoza, Pedro Lanaja, 1651, escrita en 16341636) todavía se le dedica más espacio a la estatua:

No he dicho de qué es la soberbia y cuáles son sus miembros, mas haré que lo vean todos en la estatua de Nebucadnezar: toda ella representaba monarquías y tiranías y poderíos que cayeron. Representábalos todos con oro, plata, hierro y bronce, porque la cabeza y lo más principal de la soberbia es codicia y sed de tesoros, lo que siempre fue forzosa ruina del poder y de las monarquías; el pecho y las piernas eran de bronce y de hierro, por la obstinación con que persevera y la dureza con que camina; empero los pies eran de lodo, en que se ve la flaqueza de tan rica fábrica. Ruin arquitecto es la soberbia: los cimientos pone en lo alto y las tejas en los cimientos. $\mathrm{Al}$ contrario, la sancta madre Iglesia, para fortalecernos, en la cabeza nos pone el lodo y nos manda poner el oro y la plata debajo de los pies. Todo lo entiende al revés la soberbia. Por esta razón fue castigo, de aquellos soberbios que quisieron llegar al cielo con una torre, la confusión de lenguas. Su castigo es y será siempre este y siempre es confusión de lenguas; quiero decir que ella se confunde mudando los nombres a las cosas: llama salud a la enfermedad, y grandeza la hinchazón y crecimiento el peligro, y camino el despeñadero, y descanso la carga, y poder la tiranía y premio el robo $(531) .^{13}$

Junto a un pequeño alarde de hebreo (con la forma «Nebuchadnezzar»), se repite el patrón arquitectónico ("Ruin arquitecto es la soberbia») y la crítica a la mala traza de la estatua frente a la Iglesia, que en esta última cala adquiere un nuevo sentido político (igual que en el soneto religioso, el Discurso de las privanzas y el Marco Bruto) y se combina con el mito de la torre de Babel (Génesis, 11, 1-9), que

12. Este personaje bíblico aparece de nuevo más adelante en una lista de emperadores «que pretendieron ser tenidos por dioses» (305).

13. Hay varios pasajes parecidos en el texto («El soberbio todo lo hace al revés», 518 , entre otros) e imágenes similares (ver Candelas Colodrón 2007: 43-44). 
está fuertemente ligado a Nabucodonosor y su reino como mito de origen (BabelBabilonia), según un parecido ya presente en la Homilía a la Sanctísima Trinidad. ${ }^{14}$

En una mirada de conjunto, es claro el interés de Quevedo por la imagen estatuaria de Nabuco, que aprovecha tanto en poesía como en prosa desde sus primeros pinitos, en un proceso de reescritura en el que se amplía el abanico de valores simbólicos (cortesano, jocoso, moral, político) y se le concede más coherencia y espacio, para culminar en el poema soberbio y dos tratados mayores (Providencia de Dios y Virtud militante). Dentro de esta comunidad intertextual, la hermandad es especialmente fuerte entre el soneto "A la Soberbia» y el pasaje similar de Virtud militante, que constituyen el remate de las tentativas previas: amén de la mayor complejidad y elaboración, comparten ideas (la metáfora de la arquitectura, defensa del sentido común, etc.), imágenes y lexemas ("cimiento» y los «cimientos», v. 7 y 261, la «rica locura», v. 11 / «la locura con que le mereció», 518; la "pompa», v. 2 / "pompa hechicera», 529, la contraposición con la hermosura y el poder, vv. 12-14 y 532, etc.), e intención (crítica de la apariencia, elogio de la humildad), por lo que el soneto «A la Soberbia» se puede tener por una miniversión poética del pasaje al mismo asunto de Virtud militante.

\section{Las razones de Nabuco: la fuerza de la evidentia}

Quevedo tenía al menos cuatro buenas razones para echar mano tan frecuentemente del exemplum de la estatua de Nabuco: 1) era una historia simbólica de todos conocida (con sus ventajas), que 2) se prestaba bien al tratamiento alegórico (y a la personificación), 3) contaba con una tradición visual aneja y 4) poseía sobre todo una gran fuerza de representación gráfica por la que, sin necesidad de recurrir a ningún modelo concreto, podía evocar eficazmente una imagen virtual (imaginaria) por obra y arte de una poderosa evidentia. ${ }^{15}$

La efigie de sal de la mujer de Lot (Génesis, 19, 15-26) que Quevedo recuerda alguna vez (Introducción a la vida devota, Madrid, Imprenta Real, 1634, VII, 1756b) es prima hermana de la estatua de Nabuco, que el poeta prefiere seguramente porque es una admonición previa al castigo - que no la condena final- y sobre todo por la polivalencia de la imagen, que permite abrirse a lecciones muy diversas (cortesanas, morales, políticas y religiosas) que sintetiza y comenta con todo lujo de detalles José Laínez en El Daniel cortesano (Madrid, Juan Sánchez, 1644). ${ }^{16}$

14. Sobre el dominio quevediano de la lengua hebrea, ver Fernández López (2013).

15. Para todos los detalles que comento seguidamente, remito a Plett (2012). Ver también Vega (1992: 285-343) y López Grigera (1994: 133-145). Para el uso quevediano, ver Martinengo (2000) y Escobar Borrego (2012).

16. Es una mención obligada, toda vez que se trata de la traducción del librito (Introduction à la vie dévote, 1608) de Francisco de Sales, donde también se recuerda la caída en el pecado de Lot (III, 1753a) y su borrachera con Noé (XXIX, 1850b). 
Medina Barco (2005: 12, y 146-147) ya considera que Nabuco es un «vehículo ameno» de «evidencia simbólica» que refracta "la plasticidad emblemática» y también se ha relacionado con la iconografía de Ripa de la soberbia y la humildad (Vallejo González 2015: 132-133; y 2017: 238): la una se presenta "coronata d'oro di gemme in gran copia, [...] che si dipinge bella e riccamente vestita» y es «un appetito disordinato" que se contempla engreídamente en "uno specchio» sin "volger giamai gli occhi all'imperfettione» (fol. 479), al tiempo que la otra desprecia los atuendos lujosos "per riputarsi indegna di tutti i commodi di questa vita» (fol. 214), según una oposición exterior-interior muy acorde con el pensamiento cristiano.

Es verdad que Nabucodonosor cuenta con una serie de modelos artísticos (escultóricos, pictóricos y tapiceros) y emblemáticos, pero la tradición prefiere otros lances (la locura de Daniel, 4) y sobre todo el motivo no precisa necesariamente de un reflejo real que invocar porque ya funciona por naturaleza a modo de picturas (Rey 1985: 316): ${ }^{17}$ es decir, se trata de un ejemplo de evidentia y no de écfrasis (que, además, es un tecnicismo moderno)..$^{18}$ Desde el punto de vista retórico, la estatua de Nabuco es un recurso muy potente para la persuasión y el movere: de un lado, es un exemplum que disfruta del prestigio del origen bíblico (con el plus de validez del Antiguo Testamento) y se emplea con valor moral, religioso y político; de otro, se emplea según una estrategia de ampliación más y más desarrollada mediante comentarios o glosas poéticas, que se abre a una rica expresión metafórica y visual. ${ }^{19}$

Quevedo valoraba la evidentia como una de las mejores maneras de lograr la claridad del discurso mediante el artificio de poner «delante de los ojos lo que dicen», según escribe en los preliminares a fray Luis de León (1631, 158-159) apoyándose en Lulio (De oratione, 1558) (López Grigera, 1994: 78-81; y Azaustre Galiana, 2003: 93-94). En sintonía con esta declaración teórica, la clave visual se estampa a fuego en los dos sonetos con el presente verbal (en alternancia), la semántica de ubicación espacial («estás», v. 11 del segundo), la enumeración detallada de las partes («frente» de «metal», etc., vv. 5-8 del primer poema) y

17. Rey (1985: 316) mete en el mismo saco otros elementos (el árbol ardiendo, otro plantado en tierra, la caída de san Pablo, el cohete y el retrato degradante de un monarca). Goosen (2006: 71-79) da una lista de cuadros y frescos de varios episodios de la vida del emperador, a la que hay que sumar las series de arazzi sobre Alejandro Magno y Nabucodonosor adquiridos por el rey Fernando el Católico en 1508 (Zalama Rodríguez 2016: 42).

18. La distinción entre ambas figuras (con el concepto mayor de descriptio de por medio) viene marcada por la función poética, ya que la evidentia (o hipotiposis) supone la capacidad de representar visualmente una imagen, mientras que la écfraiss se refiere modernamente a la descripción de obras de arte (reales o imaginarias): ver el panorama conceptual de Rodríguez Posada (2014). Con todo, Medina Barco (2005: 146 y 149) considera el ejemplo de Virtud militante como una «ekphrasis esculpida» o una «lectura ecfrástica».

19. Sobre la argumentación de Quevedo, ver Azaustre Galiana (2016 y 2017), quien también incide en el valor de la metáfora para transmitir ideas con más fuerza y viveza. 
sobre todo con los marcadores videndi de los tratados («Miremos», «haré que lo vean»), junto a la descripción de la soberbia con rasgos de la dimensión ilusionística del arte: así pues, se bautiza a la soberbia como "artífice engañoso" que diseña una estatua fingida y la apariencia de riqueza en los poemas (vv. 1-4 y 11), mientras en prosa se presenta cual «[m] al» $\mathrm{y}$ «ruin arquitecto».

$Y$ es que, si bien la imagen imaginaria se construye solo con el poder de las palabras, el artificio consiste en jugar intencionadamente con el modelo de una estatua bien conocida, de modo que se trata de un ejemplo de inventio a medio camino entre la descripción escultórica y la representación de una imagen totalmente ficticia, que, para rizar el rizo, remite tanto a una estatua (sońada, además) como a un personaje (con su vicio). De hecho, el patrón del primer soneto todavía es más complejo, porque la adición de la alegoría de la Soberbia como artífice hace que la estatua se vuelva más real, dejando al margen la condición onírica original, a la vez que expresa a las claras una pasión humana. ${ }^{20}$

Asimismo, el diseño del episodio en todos los casos comprende un retrato estático y dinámico — por este orden — con el que se dibujan dos momentos de la estatua (construcción y caída, vv. 1-8 y 9-11 del primer soneto, vv. 9-11 y 12-14 del segundo), de acuerdo tanto con una técnica muy quevediana como con el relato bíblico. Así, con la magia de la enargeia se logra una imagen activa que refleja un movimiento de ascenso (con valor de osadía) y descenso (castigo), según una representación $-\mathrm{y}$ recepción — visual que favorece la lección aneja en una suerte de comunicación ficticia.

Para acabar, es de interés carear brevemente la polivalencia simbólica de la estatua de Nabuco en Quevedo con su presencia en los tratados religiosos y la teoría política coetánea para tratar de apreciar cabalmente el sentido y el desarrollo del manejo quevediano. ${ }^{21}$ Efectivamente, este exemplum estatuario tenía su lugar en la oratoria sacra y los sermones de la época como símbolo de vicios (avaricia, soberbia) de gran fuerza para la predicación, así como en muchos flos sanctorum al hilo de la vida del profeta Daniel que transmiten la canónica exégesis bíblica. ${ }^{22}$ También se presenta de tanto en tanto en la tratadística política, y, así, está tres veces en las Empresas politicas de Saavedra Fajardo: primero en una lección sobre los peligros de los cortesanos más cercanos al rey («No hay en él piedra que no trabaje por desasirse y caer a derribar la estatua del valido, no

20. En la mención del «vulgar sentimiento» (159) del prefacio de Quevedo a la poesía de fray Luis de León, Martinengo (2000: 219) ve una defensa de la evidentia para expresar mensajes ejecutivos y prácticos, que en este caso sería la condena de la soberbia.

21. Para la relación de Quevedo con este tipo de géneros, ver especialmente Fernández Mosquera (1997).

22. Por ejemplo, se puede ver el emblema «Numquam alimenta recusat» (II, núm. 38) de Covarrubias (Emblemas morales, Madrid, Juan de la Cuesta, 1589), donde Nabuco se saca en relación con la avaricia. Se puede comparar con las imágenes de predicación visual (González García 2015). 
menos sujeta a deshacerse que la de Nabucodonosor, por la diversidad de sus metales», núm. 50, «Iovi et fulmini», 604-605), luego como recuerdo en negativo de asunción de la voluntad divina («No dejaron de ser ciertos los anuncios de la estatua con pies de barro que sońó Nabucodonosor por haber hecho otra de oro macizo, mandando que fuese adorada», núm. 88, "Volentes trahimur», 939) y finalmente a modo de ilustración de la constancia del buen gobierno de principio a fin («Semejantes son en su gobierno a la estatua que se representó en sueños a Nabucodonosor, los principios de oro, los fines de barro», núm. 100, "Qui legitime», 1025-1026). En todos los casos, la imagen imperial es un recurso más que no llega a ser motivo central de un emblema o texto.

En este marco, el abanico de valores religioso-morales (soberbia, vanidad de las apariencias externas, etc.) y políticos (fragilidad de las monarquías, importancia de los privados como fundamento, tiranía) de la estatua de Nabuco en Quevedo casa bien con el panorama de su tiempo. Además del acento en el sentido político que supone en cierto sentido un regreso a la exégesis bíblica habitual (sucesión de monarquías hasta la venida del reino de Dios), acaso se pueda destacar el uso del ejemplo en distintos esquemas genéricos (de las obritas burlescas al sermón militante) con variaciones de extensión y sentido, junto a la atención concedida a los aspectos visuales, que se traduce en un hábil manejo de la evidentia y todavía más en la metáfora artística (arquitectónica), por la que la soberbia se presenta significativamente como artífice de la estatua.

\section{«Va, pensiero»: final}

En fin, tanto en poesía como en prosa Quevedo aprovecha la estatua de Nabuco por su valor artístico y ejemplar, para lo que deja en segundo plano la figura del rey y hasta la exégesis bíblica al uso para presentarlo como un emblema polivalente de sentido político o religioso-moral bien asentado, tras algunos jugueteos más cómicos de juventud (en Premáticas del Desengaño contra los poetas güeros). En un continuo proceso de reescritura que comienza con breves menciones, el poeta perfecciona el manejo simbólico de la estatua de Nabuco, que gana protagonismo en dos tratados de madurez (Providencia de Dios y especialmente Virtud militante) en relación con otros géneros (con el sermón a la cabeza) y en un rico diálogo con la poesía, donde Quevedo llega a bosquejar un soneto con dos versiones - y medio poema más - dedicado por entero a la soberbia de Nabuco. Es decir: espoleado por un gusto especial, Quevedo hace que este exemplum pase de ser un recurso retórico más a un argumento principal que se vale casi por sí solo para la presentación de ideas vivas. En este sentido, también se explota más y mejor las posibilidades de la evidentia para dibujar vívidamente el pecado y su castigo frente al auditorio: así, la descripción, las emociones y la lección final se juntan en una imagen tan ejemplar como viva que, desde luego, vale más que mil palabras. 


\section{Bibliografía}

Alonso Veloso, María José (ed.), F. de Quevedo, Primera parte de la vida de Marco Bruto, en Obras completas en prosa, V, dir. A. Rey, Madrid, Castalia, 2012, 641-984.

- (ed.), F. de Quevedo, Textos atribuidos, en Obras completas en prosa, VII, dir. A. Rey, Madrid, Castalia, 2018, 849-892.

Arellano, Ignacio, «La Biblia en la poesía de Quevedo: notas sueltas», La Perinola, 8 (2004), 17-48.

Azaustre Galiana, Antonio, "Cuestiones de poética y retórica en los preliminares de Quevedo a las poesías de fray Luis de León», La Perinola, 7 (2003), 61-102.

—, "La argumentación retórica en Providencia de Dios, de Francisco de Quevedo", en Retórica aplicada a la literatura medieval y de los siglos XVI y XVII, ed. L. von der Walde Modeno, México, Destiempos, 2016, 445-495.

—, «La argumentación retórica en cuatro obras políticas de Quevedo: Grandes anales de quince días, Mundo caduco y desvarios de la edad, Política de Dios y Primera parte de la vida de Marco Bruto", La Perinola, 21 (2017), 151-206.

Blanco, Mercedes, «Babel-Babilonia en los autos sacramentales de Calderón: la estatua y la torre como símbolos del absolutismo", en El mundo maravilloso de los autos de Calderón, ed. I. Arellano y D. Reyre, Kassel / Pamplona, Reichenberger / Universidad de Navarra, 2007, 33-73.

Blecua, José Manuel (ed.), F. de Quevedo, Obra poética, Madrid, Castalia, 1969-1981, 4 vols.

Candelas Colodrón, Manuel Ángel, «La poesía religiosa de Quevedo: los sonetos sacros», Bulletin of Spanish Studies, 83.5 (2006), 637-667.

—, «La iconografía de Virtud militante de Francisco de Quevedo», La Perinola, 11 (2007), 35-49.

Covarrubias, Sebastián de, Emblemas morales, ed. S. M. ${ }^{a}$ Peñasco González, A Coruña, SIELAE / Society for Emblem Studies, 2017.

-, Tesoro de la lengua castellana o española, ed. integral e ilustrada I. Arellano y R. Zafra, Madrid / Frankfurt, Iberoamericana / Vervuert, 2006.

Davenport, Randi L., "La mujer hermosa y la estatua de palo de El mundo por de dentro de Francisco de Quevedo: el desafío epistemológico en clave escéptica», Revue Romane, 51.2 (2016), 307-322.

Escobar Borrego, Francisco J., «A vueltas sobre la tradición retórica en Francisco de Quevedo: la España defendida como monumentum propagandístico y de canonización (con un excurso sobre la pervivencia de Quintiliano)», $L a$ Perinola, 16 (2012), 165-185.

EtTinghausen, Henry, «Ideología intergenérica: la obra circunstancial de Quevedo", en Estudios sobre Quevedo: Quevedo desde Santiago entre dos aniversarios, ed. S. Fernández Mosquera, Santiago, Universidade de Santiago de Compostela, 1995, 225-259. 
Fernández López, Sergio, «Francisco de Quevedo y su conocimiento de la lengua hebrea", en Italia en la obra de Quevedo: "Roma antigua y moderna", ed. M. ${ }^{a}$ J. Alonso Veloso y A. Rey, Santiago de Compostela, Universidade de Santiago de Compostela, 2013, 183-206.

Fernández Mosquera, Santiago, «El sermón, el tratado, el memorial: la escritura interesada de Quevedo", La Perinola, 1 (1997), 63-86.

—, "Quevedo y los santos», Criticón, 92 (2004), 7-37.

-, Quevedo: reescritura e intertextualidad, Madrid, Biblioteca Nueva, 2005.

—, «Reescritura en el Siglo de Oro: diferentes estrategias autoriales», en El Siglo de Oro español: texto e imagen (Congreso Internacional, GRISO/Ermitage, San Petersburgo), ed. I. Arellano y S. Bagnó, Pamplona, Eunsa, 2010, 23-37. [Con cambios en: Calderón: texto, reescritura, significado y representación, Madrid / Frankfurt, Iberoamericana / Vervuert, 2015, 81-92.]

González García, Juan Luis, Imágenes sagradas y predicación visual en el Siglo de Oro, Madrid, Akal, 2015.

Goosen, Louis, De Abdías a Zacarías: temas del Antiguo Testamento en la religión,

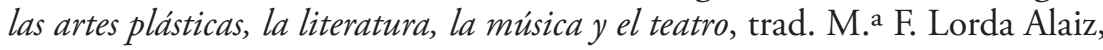
Madrid, Akal, 2006.

Krabenhoft, Kenneth, El precio de la cortesia: retórica e invención en Quevedo y Gracián, Salamanca, Universidad de Salamanca, 2004.

LaÍnez, José, El Daniel cortesano, Madrid, Juan Sánchez, 1644. [Ejemplar de la Biblioteca de Catalunya, signatura Res 202-4, disponible en Google Books, en red.]

López Grigera, María Luisa, La retórica en la España del Siglo de Oro: teoría y práctica, Salamanca, Universidad de Salamanca, 1994.

López Poza, Sagrario (ed.), F. de Quevedo, Providencia de Dios, Janus: Estudios sobre el Siglo de Oro, anexo 4, 2015. [En red.]

Martinengo, Alessandro, "La descripción del caballo (Job, 39, 19-25) y la noción de evidentia en la poética quevediana», La Perinola, 4 (2000), 143-168.

Medina Barco, Inmaculada, «Retratismo alegórigo / emblemático en la obra de Quevedo", La Perinola, 9 (2005), 125-150.

Moreno Castillo, Enrique (ed.), F. de Quevedo, Sonetos morales, Pamplona, Eunsa, 2014.

- (ed.), F. de Quevedo, Silvas morales y sonetos religiosos, Pamplona, Eunsa, 2017.

Nider, Valentina, «La prosa de Quevedo y la Biblia», en La Biblia en la literatura española: Siglo de Oro, dir. G. del Olmo Lete y coord. R. Navarro Durán, Madrid, Trotta, 2008, vol. 2, 233-264.

—, "Los clásicos desde el Siglo de Oro: de estatuas y cortesanas en los sonetos de Quevedo sobre Friné ("Polimnia" 78 y 79)», Criticón, 131 (2017), 91-108.

Plett, Heinrich F., Enargeia in Classical Antiquity and the Early Modern Age: The Aesthetics of Evidence, Leiden / Boston, Brill, 2012. 
Quevedo, Francisco de, La caida para levantarse, ed. V. Nider, Pisa, Giardini, 1994.

-, Discurso de las privanzas, ed. E. M. a Díaz Martínez, en Obras completas en prosa, V, dir. A. Rey, Madrid, Castalia, 2012, 87-156.

-, Homilia de la Santísima Trinidad y Homilía a la Sanctísima Trinidad, ed. A. Rey, en Obras completas en prosa, VII, dir. A. Rey, Madrid, Castalia, 2018, 205-245.

-, Introducción a la vida devota, en Obras completas (obras en prosa), ed. F. Buendía, Madrid, Aguilar, 1979, 1740-1906.

—, Obra poética, ed. J. M. Blecua, Madrid, Castalia, 1969-1981, 4 vols.

-, Papel de las cosas corrientes en la corte, por abecedario, ed. A. Azaustre Galiana, en Obras completas en prosa, II, 1, dir. A. Rey, Madrid, Castalia, 2007, 349-385.

—, Poesía moral («Polimnia»), ed. A. Rey, 2. ${ }^{\text {a }}$ ed. revisada y ampliada, Madrid, Tamesis, 1999.

-, Preliminares literarios a las poesías de fray Luis de León, ed. A. Azaustre Galiana, en Obras completas en prosa, I, 1, dir. A. Rey, Madrid, Castalia, 2003, 119-161.

—, Premáticas del Desengaño contra los poetas güeros, ed. A. Azaustre Galiana, en Obras completas en prosa, I, 1, dir. A. Rey, Madrid, Castalia, 2003, 1-18.

-, Primera parte de la vida de Marco Bruto, ed. M.a J. Alonso Veloso, en Obras completas en prosa, $V$, dir. A. Rey, Madrid, Castalia, 2012, 641-984.

—, Providencia de Dios, ed. S. López Poza, Janus: Estudios sobre el Siglo de Oro, anexo 4, 2015. [En red.]

-, Textos atribuidos, ed. M. ${ }^{\mathrm{a}}$ J. Alonso Veloso, en Obras completas en prosa, VII, dir. A. Rey Madrid, Castalia, 2018, 849-892.

-, Virtud militante contra las cuatro pestes del mundo: invidia, ingratitud, soberbia, avaricia, ed. A. Rey, en Obras completas en prosa, IV.2, dir. A. Rey, Madrid, Castalia, 2010, 445-563.

Rey, Alfonso (ed.), F. de Quevedo, Virtud militante, Santiago de Compostela, Universidade de Santiago de Compostela, 1985.

—, Quevedo y la poesía moral española, Madrid, Castalia, 1995.

- (ed.), F. de Quevedo, Poesía moral («Polimnia»), 2. ${ }^{\text {a }}$ ed. revisada y ampliada, Madrid, Tamesis, 1999.

Ripa, Cesare, Iconologia, Roma, Lepido Facii, 1603.

Rodríguez Posada, Adolfo, «La pintura verbal: aproximación a los conceptos de descripción, hipotiposis y écfrasis desde la retórica y la teoría literaria», Crossing Boundaries in Culture and Communication, 5.2 (2014), 121-131.

Roig Miranda, Marie, Les sonnets de Quevedo: variations, constance, évolution, Nancy, Presses Universitaires de Nancy, 1989.

Rubio Árquez, Marcial, y Adrián J. SÁEZ, «El efecto Pigmalión: la poesía escultórica en el Siglo de Oro", en La estirpe de Pigmalión: poesía y escultura en el Siglo de Oro, ed. M. Rubio Árquez y A. J. Sáez, Madrid, SIAL, 2017, 7-26. 
SaAvedra Fajardo, Diego, Empresas politicas, ed. S. López Poza, Madrid, Cátedra, 1999.

SÁez, Adrián J., "Aretino y Quevedo: perfiles de la poesía pictórica", Calíope: Journal of the Society for Renaissance and Baroque Poetry, 20.2 (2015a), 119149.

-, El ingenio del arte: la pintura en la poesía de Quevedo, Madrid, Visor Libros, 2015b.

—, "Entre el pincel y la pluma: boceto sobre la poesía de Quevedo y la pintura», en El duque de Medina Sidonia: mecenazgo y renovación estética, ed. J. M. Rico García y P. Ruiz Pérez, Huelva, Universidad de Huelva, 2015c, 381-398.

—, “"Las aves del imperio coronadas”: poesía y arte en el túmulo de Quevedo a sor Margarita de Austria», Artifara, 15 (2015d), 213-222. [En red.]

—, "Quevedo y Armenini: lecturas pictóricas de un poeta", Janus: Estudios sobre el Siglo de Oro, 4 (2015e), 1-24. [En red.]

-, "Quevedo y el arte de la tapicería: el romance "Matraca de los paños y sedas"», Boletín de la Real Academia Española, 95.312 (2015f), 453-470.

—, "Las estatuas de Quevedo: arte y encomio funeral en un poema al duque de Osuna", en La estirpe de Pigmalión: poesía y escultura en el Siglo de Oro, ed. M. Rubio Árquez y A. J. Sáez, Madrid, SIAL, 2017a, 217-231.

—, "El perdón de la Magdalena: erotismo y pintura en un soneto de Quevedo», en "En la concha de Venus amarrado»: erotismo y literatura en el Siglo de Oro, ed. P. Marín Cepeda, Madrid, Visor Libros, 2017b, 107-120.

—, "Reyes de bronce: tres poemas escultóricos de Quevedo», Janus: Estudios sobre el Siglo de Oro, 6 (2017c), 211-229. [En red.].

—, "Corazón de piedra: escultura y poesía en el madrigal "Retrato de Lisi en mármol" de Quevedo", Versants: revue suisse des littératures romanes, 65.3 (2018), 137-148.

—, "Quevedo and the Mirror: Poetry, Painting and the Problem of Beauty», en The Dialectics of Faith and Doubt in Seventeenth-Century Spain: Visual and Literary Reflections, ed. M. Ancell y A. Georgievska-Shine, Toronto, Toronto University Press, en prensa.

Tobar Quintanar, María José, «La autoridad de El Parnaso español y Las tres musas últimas castellanas: criterio editorial para la poesía de Quevedo», $L a$ Perinola, 17 (2013), 335-356.

Vallejo González, María, «Las imágenes del pecado en la poesía religiosa de Quevedo", en Sobremesas literarias: en torno a la gastronomía en las letras hispánicas, ed. J. Murillo Sagredo y L. Peña García, Madrid, ALEPH / Biblioteca Nueva / Fundación San Millán de la Cogolla, 2015, 127-138.

- La poesía religiosa de Quevedo: edición crítica y anotada de "Urania", Santiago de Compostela, Universidade de Santiago de Compostela, 2017. [Tesis doctoral inédita.]

Varela Gestoso, Mónica Inés, “"Declaraciones de Jesucristo a su eterno Padre en el Huerto" yunos sonetos de Quevedo", en Actas del IV Congreso Interna- 
cional de la Asociación Internacional Siglo de Oro (Alcalá de Henares, 22-27 de julio de 1996), ed. M. ${ }^{a}$ C. García de Enterría y A. Cordón Mesa, Alcalá de Henares, Universidad de Alcalá de Henares, 1998, vol. 2, 1611-1620.

VEGA, María José, El secreto artificio: "qualitas sonorum» y tradición pontaniana en la poética del Renacimiento, Madrid, CSIC, 1992.

Zalama Rodríguez, Miguel Á., «The Ceremonial Decoration of the Alcázar in Madrid: The Use of Tapestries and Paintings in Habsburg Festivities», en Festival Culture in the World of the Spanish Habsburgs, ed. F. Checa Cremades y L. Fernández-González, Londres / Nueva York, Routledge, 2016, 41-66. 